\title{
Methodology of the fasting sub-sample from the Mexican Health Survey, 2000
}

\author{
Simón Barquera, MD, MS, PhD,(') Citlalli Carrión MC, M en C,(1) Ismael Campos, MD, MS,(') Juan Espinosa, MS,(1) \\ Juan Rivera, MS, PhD, (I) Gustavo Olaiz-Fernández, MD, MSP.(2)
}

\begin{abstract}
Barquera S, Carrión MC, Campos I, Espinosa J, Rivera JA, Olaiz-Fernández G. Methodology of the fasting sub-sample from the Mexican Health Survey, 2000. Salud Publica Mex 2007;49 supl 3:S42I-S426.
\end{abstract}

\begin{abstract}
Objective. To report the comparative results of the sub-sample of fasting adults selected for the biochemical measurement of cardiovascular risk factors and the rest of the Mexican Health Survey (MHS) (2000) participants. Material and Methods. The nationally representative, cross-sectional Mexican Health Survey (2000) was analyzed. Survey participants reporting a fasting state period of 9- to 12 -h were included in a sub-sample $(n=2535)$ and compared with all other participants $(n=4 \mid \quad 126)$. Prevalence and 95\% confidence intervals $(95 \% \mathrm{Cl})$ were calculated for socio-demographic, anthropometric, health and personal background characteristics and compared between groups using Pearson $\chi^{2}$ to determine significant differences. Mean and $95 \% \mathrm{Cl}$ and a T-test were calculated to analyze continuous variables. $\mathbf{R e}$ sults. From the 45294 adults participating in the MHS, 5.59\% were at fasting state.The fasting sub-sample (FS) had a higher male-to-female ratio and was on average 3.5 years younger than the non-fasting participants (NF) and had a $1.5 \mathrm{~cm}$ wider average waist circumference. No differences were found in location, country region, socio-economic status, indigenous population, or literacy. Also, no differences were found in weight, height, BMI, systolic and diastolic blood pressure, prevalence of diabetes mellitus, previous medical diagnosis of dislypidemias, or tobacco or alcohol consumption. Conclusion. This paper documents the characteristics of the fasting sub-sample from the Mexican Health Survey (MHS). Overall, the non-fasting participants had no relevant differences that can contribute to generate biased results in the analysis of biochemical indicators of cardiovascular risk.
\end{abstract}

Keywords: obesity; diabetes mellitus high blood pressure; national surveys; Mexico
Barquera S, Carrión MC, Campos I,

Espinosa J, Rivera JA, Olaiz-Fernández G.

Metodología de la submuestra de suero

de la Encuesta Nacional de Salud 2000.

Salud Publica Mex 2007;49 suppl 3:S42 I-S426.

\section{Resumen}

Objetivo. Reportar los resultados comparativos de la submuestra de adultos en ayuno, seleccionados para la medición bioquímica de factores de riesgo cardiovascular y el resto de los participantes de la Encuesta Nacional de Salud (ENSA) 2000. Material y métodos. Se analizó la ENSA, una encuesta transversal y representativa a nivel nacional. Los participantes que reportaron un período de ayuno de 9- a I2-h se incluyeron en la submuestra $(n=2,535)$ y se compararon con el resto de los participantes $(n=4 I, 126)$. Se calculó la prevalencia e intervalo de confianza del 95\% (IC95\%) para las características sociodemográficas, antropométricas, de salud y antecedentes personales, $y$ se compararon entre los grupos utilizando $\chi^{2}$ de Pearson para determinar diferencias significativas. Asimismo, se calcularon medianas con su IC95\% y prueba de T para analizar las variables continuas. Resultados. De los 45294 adultos que participaron en la ENSA, $5.59 \%$ estuvieron en ayuno. La submuestra de ayuno (SA) tuvo una razón hombre-mujer más alta y fue en promedio 3.5 años más joven que el resto de los participantes (NA). Asimismo, tuvieron una cintura promedio $1.5 \mathrm{~cm}$ más grande. No se encontraron diferencias en localidad, región, nivel socioeconómico, población indígena o educación. Tampoco se encontraron diferencias en peso, talla, IMC, presión sistólica ni diastólica, prevalencia de diabetes mellitus, diagnóstico previo de dislipidemias, y consumo de tabaco y alcohol. Conclusión. Esta comunicación documenta las características de la muestra de ayuno de la ENSA. En general, los participantes en ayuno no tuvieron diferencias relevantes que puedan contribuir a generar resultados sesgados en el análisis de indicadores bioquímicos de riesgo cardiovascular.

Palabras clave: obesidad; diabetes mellitus; presión arterial alta; Encuesta Nacional de Salud; México

(I) Instituto Nacional de Salud Pública. México.

(2) Secretaría de Salud. México

Received on: October 30, 2006 - Accepted on: February 7, 2007

Address reprint requests to: Dr. Simón Barquera, Instituto Nacional de Salud Pública. Av. Universidad 655,

Col. Santa María Ahuacatitlán. 62508 Cuernavaca, Morelos, Mexico.

E-mail: sbarquera@insp.mx 
$\mathrm{T}$ he prevalence and characteristics of chronic diseases and obesity in Mexico have been documented using diverse national databases such as the Mexican Nutrition Surveys I and II $(1988,1999),{ }^{1,2}$ and the Mexican Chronic Diseases Survey (1994), ${ }^{3}$ among others. During 1999 and 2000, the National Institute of Public Health implemented a national health survey (Mexican Health Survey 2000) that is representative of adult men and women 20 years of age or older from across all the states and urban and rural locations. ${ }^{4}$ This survey collected casual blood samples of most of the participants interviewed. These samples were frozen for future studies, giving an invaluable opportunity to study biochemical indicators for risk of chronic diseases and provide information regarding the actual status of diverse diseases such as dislypidemias, high blood pressure, diabetes mellitus and their association with obesity. The purpose of this brief report is to communicate the comparative results of the sub-sample of fasting adults, which were selected for the biochemical measurement of cardiovascular risk factors, and the rest of the survey participants.

\section{Material and Methods}

The present study used data from the nationally representative, cross-sectional MHS, implemented in $2000 .{ }^{4} \mathrm{~A}$ multi-stage sampling procedure was used. A detailed description of the sampling design and methods is available in another publication. ${ }^{5}$ From the primary sampling units, a total of 45726 households were selected, from which 24856 men and 26747 women over the age of 20 years from urban and rural areas participated in the survey. A structured questionnaire was used to obtain socio-demographic data, family history, clinical symptoms, and medical treatment for various chronic diseases. A single blood sample was drawn by trained personnel from approximately 44000 cases and the serum was frozen at $150^{\circ} \mathrm{C}$ degrees until analysis.

\section{Anthropometric variables}

Following internationally accepted techniques, standardized personnel measured height to the nearest 0.1 cm using a stadiometer (model 202, Seca Ltd, Birmingham, UK) and weight using a digital scale (1631 solar scale, Tanita Corp, Tokyo, Japan) with a margin of error of $5 \mathrm{~mm}$ and $0.1 \mathrm{~kg}$, respectively. Waist circumference (WC) was measured at the midpoint between the highest part of the iliac crest and the lowest part of the ribs margin of the median axial line. The body mass index (BMI) was calculated by dividing the weight in kilograms by the height in $\mathrm{m}^{2}$ and was categorized according to the
World Health Organization (WHO) cut-off points into: normal weight $\left(18.5-24.9 \mathrm{~kg} / \mathrm{m}^{2}\right)$, overweight (25-29.9 $\left.\mathrm{kg} / \mathrm{m}^{2}\right)$ and obesity $\left(\geq 30 \mathrm{~kg} / \mathrm{m}^{2}\right)$; ${ }^{6}$ if WC was $\geq 102 \mathrm{~cm}$ in males or $\geq 88 \mathrm{~cm}$ in females, the subject was classified as having abdominal adiposity based on the National Institutes of Health guidelines.

\section{Geographic regions}

The regions were defined as follows: North region (Baja California, Southern Baja California, Coahuila, Durango, Nuevo Leon, Sonora, Sinaloa, Tamaulipas and Zacatecas), Central region (Aguascalientes, Colima, Guanajuato, Hidalgo, Jalisco, Mexico, Michoacan, Nayarit, Queretaro, San Luis Potosi and Tlaxcala), Metropolitan area of Mexico City, and South Region (Campeche, Chiapas, Guerrero, Morelos, Oaxaca, Puebla, Quintana Roo, Tabasco, Veracruz and Yucatan). This regionalization scheme has been used in many epidemiologic transition analyses for within-country comparisons. ${ }^{8,9}$

\section{Socioeconomic status index}

For the purpose of this study, a principal components analysis (PCA) was performed on household characteristics (flooring material, ceiling, walls, water source, drainage, number of persons residing in the household, and number of domestic appliances). The main factor extracted explained $40.4 \%$ of the total variance with a Kaiser-Mayer-Olkin (KMO) measure of sampling adequacy $=0.83$ and was used as a proxy for socioeconomic status (SES). This factor had large loadings for household and community characteristics such as sewer system, indoor plumbing, refrigerator, and television. Small loadings were observed for variables such as communal food distribution and number of people residing in the household. For the purpose of this article, this factor was divided into tertiles and used as a proxy for low, medium, and high socio-economic level.

\section{Diabetes mellitus and high blood pressure definitions}

Blood samples were collected and blood glucose was assessed using a capillary glucose test with a glucometer (AccutrendSensor Comfort, Lakeside; Roche Diagnostic Corporation, Indianapolis, IN, USA) in fasting conditions. The American Diabetes Association's criteria were utilized to identify diabetes mellitus, defined as the presence of diabetes symptoms along with a casual plasma glucose concentration $\geq 200 \mathrm{mg} / \mathrm{dl}$ or a fasting glucose $\geq 126 \mathrm{mg} / \mathrm{dl}$ and / or a previous diagnosis by a physician. ${ }^{10}$ Blood pressure was measured twice. The 
first reading was carried out after at least five minutes of rest in a seated position. The same trained nurse took both measures within five minutes of each other on the subjects' right arm using an aneroid sphygmomanometer (TJX-10, ADEX Products, Mexico City, Mexico). The first Korotkoff noise marked the systolic blood pressure and the fifth noise, the diastolic blood pressure. Criteria from the Expert Panel on Detection, Evaluation, and Treatment of High Blood Cholesterol in Adults (Adult Treatment Panel III), ${ }^{7}$ were utilized to identify high blood pressure, documented if the subject presented a diastolic blood pressure $\geq 130 \mathrm{mmHg}$ on the first reading and/or if the diastolic blood pressure was $\geq 85 \mathrm{mmHg}$, and they were confirmed by means of a second measure. In addition, all patients who said to have been previously diagnosed with hypertension by a physician were considered to have high blood pressure.

\section{Other sociodemographic variables}

Education was stratified into three groups: 1) primary or less, 2) more than primary and less than high school education, and 3) high school or more education. Literacy was defined as the percentage of the population capable of reading. Participants living in a household in which an indigenous language was spoken were considered to be indigenous. ${ }^{11}$

\section{Identification of the fasting sub-sample}

During the interview the participants reported as either having or not having a 9- to 12-h fasting state period. With this information, all individuals identified as positive were included in the fasting sub-sample ( $n=2535)$. No attempt was made in the original National Health Survey design to obtain a probabilistic sample of fasting adults; therefore, this subgroup is considered a casual sub-sample from the National Health Survey.

\section{Statistical analysis}

Due to the characteristics of the survey, the present study adjusted for the complex multistage sample design using the STATA 8.2 "SVY" module.*

To compare fasting with non-fasting cases, their prevalence and corresponding $95 \%$ confidence intervals $(95 \% \mathrm{CI})$ were calculated and a Pearson $\mathrm{X}^{2}$ test was used to establish significant differences between categories.

\footnotetext{
* Stata Corp. Stata reference manual. Release 7. College Station, TX, USA. Stata Press, 2001.
}

Mean and $95 \% \mathrm{CI}$ were calculated for continuous variables. Information related to their socio-demographic characteristics, health conditions, and personal and family background were analyzed.

\section{Ethical considerations}

Consent for participation was obtained from all participants. The project was approved by the scientific and ethics committees of the Mexican National Institute of Public Health. In addition, data collection was implemented considering the confidentiality and reserve rights stipulated by the Mexican Statistical and Geographic information law. ${ }^{12}$

\section{Results}

From the 45294 adults participating in the survey, 5.59\% were at fasting state during the blood collection $(n=2535)$. Table I summarizes the socio-demographic characteristics of the fasting and non-fasting participants. A slightly higher male-to-female ratio was observed in the fasting group. In addition, the prevalence of participants with high school or more education was higher (35.5 fasting versus $29.3 \%$ non-fasting). There were no significant differences in location (rural/urban), country region, socio-economic status index, indigenous population, or literacy. Table II summarizes personal characteristics such as anthropometric information and prevalence for diabetes mellitus (DM) or high blood pressure (HBP). The fasting group was on average 3.5 years younger than the non-fasting group. No differences were found in the average height, weight, BMI, or systolic and diastolic blood pressure. By BMI category, there were no differences between fasting and non-fasting groups for the prevalence of normal, overweight, and obese participants. Waist circumference of non-fasting participants was on average $1.5 \mathrm{~cm}$ wider compared to the fasting group ( $93 \mathrm{~cm}$ versus $91.5 \mathrm{~cm}$, respectively). The non-fasting group showed $4.6 \%$ more cases of central obesity using the ATPIII criteria compared to the fasting group ( 40.9 versus $36.3 \%$ respectively). These differences were maintained after disaggregating by sex, but remained insignificant. The prevalence of DM was similar in both groups, but the survey found that this condition was more prevalent in the fasting group. There were no significant differences in high blood pressure prevalence. A remarkably low percentage of the population had a previous medical diagnosis of high blood cholesterol in both non-fasting and fasting groups (Table II). Table III presents the personal and family background of the participants. No difference was observed between the groups for tobacco and alcohol consumption. Finally, no 
Table I

SOCIO-DEMOGRAPHIC CHARACTERISTICS BETWEEN FASTING AND NON-FASTING PARTICIPANTS from the National Health Survey 2000, Mexico

\begin{tabular}{|c|c|c|c|c|c|}
\hline \multirow[b]{2}{*}{ Sex* } & \multirow[t]{2}{*}{$\begin{array}{c}\text { Total participants N }=54294 \\
N\end{array}$} & \multicolumn{2}{|c|}{$\begin{array}{c}\text { Non fasting } N=41 \quad 126 \\
\% \text { (IC } 95 \%)\end{array}$} & \multicolumn{2}{|c|}{$\begin{array}{c}\text { Fasting } N=2535 \\
\% \text { (IC 95\%) }\end{array}$} \\
\hline & & & & & \\
\hline Male & 14666 & 46.8 & $(45.5,48.0)$ & 51.6 & $(48.7,54.5)$ \\
\hline Female & 30628 & 53.2 & $(52.0,54.4)$ & 48.4 & $(45.5,5 \mid .3)$ \\
\hline \multicolumn{6}{|l|}{ Age Group* } \\
\hline $20-39$ & 24062 & 59.9 & $(58.9,60.9)$ & 68.4 & $(65.4,71.3)$ \\
\hline $40-59$ & 13910 & 27.6 & $(26.8,28.3)$ & 23.6 & $(21.3,26.1)$ \\
\hline$\geq 60$ & 7296 & 12.5 & $(I I .9, \mid 3.1)$ & 8.0 & $(6.7,9.4)$ \\
\hline \multicolumn{6}{|l|}{ Location* } \\
\hline Rural & 21651 & 47.9 & $(42.2,53.6)$ & 40.8 & $(34.0,48.4)$ \\
\hline Urban & 23643 & 52.1 & $(46.4,57.8)$ & 59.2 & $(5 I .6,66.3)$ \\
\hline \multicolumn{6}{|l|}{ Region } \\
\hline North & II 229 & 20.0 & $(14.9,26.4)$ & 17.3 & $(\mid 2.0,24.2)$ \\
\hline Central & 17165 & 40.1 & $(32.6,48.2)$ & 43.4 & $(34.2,53.0)$ \\
\hline Mexico city & 1299 & 9.7 & $(5.0,17.8)$ & 12.7 & $(6.2,24.2)$ \\
\hline South & 15601 & 30.2 & $(24.2,37.0)$ & 26.7 & $(19.6,35.2)$ \\
\hline \multicolumn{6}{|l|}{ Socio-economic index $x^{\ddagger}$} \\
\hline Low & 14614 & 29.1 & $(25.7,32.7)$ & 26.9 & $(22.6,31.8)$ \\
\hline Medium & 14395 & 32.0 & $(30.2,33.8)$ & 31.3 & $(28.2,34.6)$ \\
\hline High & 14614 & 38.9 & $(35.6,42.4)$ & 41.7 & $(37.1,46.6)$ \\
\hline \multicolumn{6}{|l|}{ Education* } \\
\hline Primary or less & 22168 & 47.7 & $(45.5,49.9)$ & 41.4 & $(37.3,45.5)$ \\
\hline Secondary & 8271 & 23.0 & $(21.9,24.2)$ & 23.1 & $(21.0,25.4)$ \\
\hline High school or more & 10341 & 29.3 & $(27.5,3 \mathrm{I} . \mathrm{I})$ & 35.5 & $(32.0,39.2)$ \\
\hline Literacy & 39980 & 90.8 & $(89.7,91.7)$ & 92.5 & $(90.7,94.0)$ \\
\hline Indigenous population* & 3776 & 6.9 & $(5.2,9.1)$ & 4.8 & $(3.1,7.5)$ \\
\hline
\end{tabular}

* Statistically significant difference using Pearson $\chi^{2}(p<0.05)$

‡ Socioeconomic index tertile obtained from a principal component analysis of household and community characteristics (see methods). Statistical analyses were done considering the stratified survey design and the multiple stage survey design

difference was observed for family history of DM, HBP, and cardiovascular disease.

\section{Discussion}

This paper documents the characteristics of the fasting sub-sample from the Mexican Health Survey (MHS). Overall, the non-fasting and fasting groups have no relevant differences that can contribute to bias in the interpretation of biochemical cardiovascular risk indicators in the latter group.

It is likely that fasting samples were collected earlier, explaining why the frequency of males in the fasting group was higher than the rest the sample. Abdominal obesity was significantly different between the groups, even after adjusting by age; however, it was not significantly different after stratifying by sex.

The grouping into four country regions, in which three regions aggregate states and Mexico City as a single region, resulted in a very low proportion of cases for this area. This could compromise some analyses that are stratified by region, this results must be analyzed carefully.

In conclusion, the strategy of analyzing the fasting participants for biochemical indicators of chronic diseases could result in valid indicators for a sub-sample population of the Mexican Health Survey without significant differences from the rest of the survey par- 
Table II

Health conditions between non fasting and fasting participants from the National Health Survey 2000, Mexico

\begin{tabular}{|c|c|c|c|}
\hline & $\begin{array}{c}\text { Total participants } \\
N\end{array}$ & $\begin{array}{c}\text { Non fasting } \\
\text { Mean (IC 95\%) }\end{array}$ & $\begin{array}{c}\text { Fasting } \\
\text { Mean (IC 95\%) }\end{array}$ \\
\hline Age (years)* & 45268 & $39.1 \quad(38.8,39.4)$ & $35.6 \quad(34.6,36.5)$ \\
\hline Height $(\mathrm{cm})^{*}$ & 43246 & $158.6(158.3,159.0)$ & $159.7(159.0,160.5)$ \\
\hline Weight (Kg) & 42093 & $68.6 \quad(68.0,69.1)$ & $68.2(67.3,69.2)$ \\
\hline BMI $\left(\mathrm{kg} / \mathrm{m}^{2}\right)^{*}$ & $4|68|$ & $27.0 \quad(26.9,27.2)$ & $26.6 \quad(26.3,26.9)$ \\
\hline Systolic blood pressure $(\mathrm{mm} / \mathrm{Hg})^{*}$ & 43694 & $122.1 \quad(121.8,122.5)$ & $120.9(\mid 19.8,121.9)$ \\
\hline Dyastolic blood pressure $(\mathrm{mm} / \mathrm{Hg})$ & 43694 & $79.8 \quad(79.5,80.1)$ & $79.3 \quad(78.5,80.1)$ \\
\hline \multirow[t]{2}{*}{ Waist circumference $(\mathrm{cm})^{*}$} & 40913 & $93.0 \quad(92.6,93.4)$ & $91.5 \quad(90.6,92.3)$ \\
\hline & $\mathrm{N}$ & $\%$ (IC 95\%) & $\%$ (IC 95\%) \\
\hline \multicolumn{4}{|l|}{ BMI category $\left(\mathrm{kg} / \mathrm{m}^{2}\right)$} \\
\hline Normal & 14550 & $37.8 \quad(36.6,39.1)$ & $41.8 \quad(38.8,44.9)$ \\
\hline Overweight & 15745 & $38.3 \quad(37.3,39.3)$ & $37.1 \quad(33.9,40.4)$ \\
\hline Obesity & II 386 & $23.9 \quad(22.9,24.8)$ & $21.1 \quad(18.9,23.5)$ \\
\hline Central Obesity $\ddagger * *$ & 20662 & $40.9 \quad(39.7,42.0)$ & $36.3 \quad(33.4,39.2)$ \\
\hline Females & 17509 & $59.0 \quad(57.8,60.3)$ & $56.0 \quad(52.7,59.2)$ \\
\hline Males & 3153 & $21.1 \quad(19.8,22.4)$ & $18.2 \quad(14.4,22.7)$ \\
\hline DM diagnosis with capillary test* & 2290 & $(4.2,4.9)$ & $(4.9,7.6)$ \\
\hline Previous DM diagnosis* & 2956 & $5.8 \quad(5.4,6.2)$ & $4.3 \quad(3.4,5.3)$ \\
\hline DM2 (survey finding + previous diagnosis) & 3764 & $(7.1,7.9)$ & $(6.2,9.3)$ \\
\hline High Blood Pressure (survey finding) ${ }^{*}$ & 14407 & $31.0 \quad(29.8,32.2)$ & $27.8 \quad(25.1,30.7)$ \\
\hline Previous HBP diagnosis & 6508 & $14.9 \quad(14.3,15.6)$ & $12.4 \quad(10.2,15 . I)$ \\
\hline HBP (survey finding + previous diagnosis) & 15212 & $32.3 \quad(31.2,33.5)$ & $28.1 \quad(25.4,3 \mathrm{I} . \mathrm{I})$ \\
\hline Previous high blood Cholesterol diagnosis & 3274 & $6.8 \quad(6.3,7.3)$ & $6.1 \quad(4.8,7.6)$ \\
\hline
\end{tabular}

Table III

FAmily AND PERSONAL background betWeEn NON-FASTING AND FASTING PARTICIPANTS from the Mexican Health Survey, Mexico 2000

Total participants

N

Smoked 100 cigarettes

\begin{tabular}{|c|c|c|c|}
\hline Never have smoked & 16715 & $31.01(29.2,33.0)$ & $31.0 \quad(27.9,34.4)$ \\
\hline Less than 100 & 14165 & $32.8 \quad(31.4,34.3)$ & $32.2(29.0,35.7)$ \\
\hline More than 100 & 13248 & 36.I $\quad(34.7,37.6)$ & $36.7 \quad(33.6,40.0)$ \\
\hline urrently smoker & 7470 & $61.4 \quad(59.5,63.1)$ & $66.7 \quad(61.3,71.9)$ \\
\hline nokes daily & 7743 & $43.0 \quad(41.7,45.8)$ & $47.2(42.2,52.3)$ \\
\hline urrently alcohol drinker & 15416 & $65.9 \quad(64.2,67.5)$ & $66.7 \quad(6 I .7,7 I .2)$ \\
\hline rinks daily & 1386 & $5.6 \quad(5.0,6.3)$ & $7.4 \quad(5.2,10.3)$ \\
\hline M family history & 13199 & $34.0 \quad(32.8,35.3)$ & $31.8 \quad(28.9,34.8)$ \\
\hline BP family history & 16402 & $43.5 \quad(41.7,45.3)$ & $43.4 \quad(39.8,47.0)$ \\
\hline earth disease family history & 9630 & $23.6 \quad(22.5,24.7)$ & 2I.I $(18.9,23.6)$ \\
\hline
\end{tabular}

* Statistically significant differences using a Pearson $\chi^{2}$ test $(p<0.05)$. All statistics were calculated considering the stratified multi-stage survey design $($ see methods) 
ticipants in most socio-demographic, anthropometric, and health conditions. However, the resulting number of cases limits the ability to detect significant differences after stratifying by region or when analyzing events that occur at a very low rate. In future surveys, new strategies will be implemented to assure a higher number of participants at fasting state.

\section{Acknowledgments}

This study was possible thanks to the Mexican National Council of Science and Technology (CONACyT) grant number 37194-M (Barquera S, Olaiz G, Villalpando S, Rivera J, González C, Sepúlveda J. Contribution of overweight and obesity to the development of risk factors for chronic diseases: analysis of the National Health Survey). We would like to acknowledge the assistance of Oswaldo Palma, MS, Rosalba Rojas, MD, PhD, Carlos Conde, PhD and Ricardo Robledo, PhD, who provided valuable assistance in identifying and processing the fasting sub-sample from the MHS.

\section{References}

I. Sepulveda-Amor, J, Lezana, MA, Tapia-Conyer, R, Valdespino, JL, Madrigal, $\mathrm{H}$, Kumate, J. Estado nutricional de preescolares y mujeres en México: resultados de una encuesta probabilística poblacional. Gac Med Mex 1990;126:207-224.
2. Rivera, J, Shamah, T,Villalpando, S, González-Cossio, T, Hernández, B, Sepúlveda,J. Encuesta Nacional de Nutrición 1999: Estado nutricio de niños y mujeres en México. Mexico: Instituto Nacional de Salud Publical Secretaría de Salud, 2000.

3.Aguilar-Salinas CA, Olaiz G,Valles V, Rios-Torres J, Gómez-Pérez FJ, Rojas $R$ et al. High prevalence of low HDL cholesterol concentrations and mixed hyperlipidemia in a Mexican nationwide survey.J Lipid Res 200 I;42: I298-I307.

4. Olaiz G, Rojas R, Barquera S, Shamah T,Aguilar C, Cravioto P. Encuesta Nacional de Salud 2000. Tomo 2: La salud de los adultos. Cuernavaca, Morelos, México, Instituto Nacional de Salud Pública, 2003.

5. Instituto Nacional de Salud Pública. Encuesta Nacional de Salud (ENSA) 2000. Mexico DF: Secretaría de Salud, 2000.

6. World Health Organization. Physical status: the use and interpretation of anthropometry. Geneva: WHO, 1995.

7. Expert panel on detection evaluation and treatment of high blood cholesterol in adults. Executive summary of the third report of the national cholesterol education program (NCEP) expert panel on detection, evaluation and treatment of high blood cholesterol in adults (adult treatment panel III). JAMA 2002;287:356-359.

8. Hernandez-Diaz S, Peterson K, Dixit S, Hernandez B, Parra S, Barquera S.Association of maternal short stature with stunting in Mexican children: common genes vs common environment. Eur Clin Nutr 1999;53:938-945. 9. Barquera S, Tovar-Guzmán V, Campos-Nonato I, González-Villalpando C, Rivera-Dommarco J. Geography of diabetes mellitus mortality in Mexico: an epidemiologic transition analysis. Arch Med Res 2003;34:407-4I4.

10.American Diabetes Association. Diagnosis and classification of diabetes mellitus. Diabetes Care 2006;29 Supl I:S43-48.

I I.Valdespino J, Olaiz G, López-Barajas M, Mendoza L, Palma O,Velázquez O. Encuesta Nacional de Salud. Tomo I. Cuernavaca, Morelos, México: Instituto Nacional de Salud Pública, 2003.

12. Ley de Información Estadística y Geográfica. Diario Oficial de la Federación. Estados Unidos Mexicanos, 1980. 